\title{
Identification, Assessment and Mitigation of Environment Side Risks for Malaysian Manufacturing
}

\author{
Muhammad Saeed Shahbaz \\ Faculty of Technology Management and \\ Business, Universiti Tun Hussein \\ Onn Malaysia, Batu Pahat, \\ Johor, Malaysia \\ msaeed.shahbaz@gmail.com
}

\section{Mudaser Javaid}

Faculty of Technology Management and Business, Universiti Tun Hussein Onn

Malaysia, Batu Pahat,

Johor, Malaysia

mudaserjavaid@gmail.com

\author{
Abdul Ghafoor Kazi \\ Department of Management Science, \\ Shaheed Zulfiqar Ali Bhutto Institute of \\ Science and Technology, Hyderabad, \\ Sindh, Pakistan \\ agkazi78@gmail.com
}

Khawar Hussain

Faculty of Technology Management and Business, Universiti Tun Hussein

Onn Malaysia, Batu Pahat, Johor, Malaysia

khawarpm786@gmail.com

\author{
Bestoon Othman \\ Erbil Polytechnic University, Iraq, and \\ Faculty of Technology Management and \\ Business, Universiti Tun Hussein Onn \\ Malaysia, Malaysia \\ bestoon2011@yahoo.com
}

Raja Zuraidah R. M. Rasi

Faculty of Technology Management and Business, Universiti Tun Hussein Onn

Malaysia, Batu Pahat, Johor, Malaysia rzuraidah@uthm.edu.my

\begin{abstract}
Malaysia has faced many supply chain issues that not only have affected enterprises but also the overall economy. Natural disasters that badly affect the performance of Malaysian enterprises strongly demand a comprehensive investigation of supply chain risks. Effective mitigation strategy can only be operationalized when risks are appropriately identified and assessed. Supply chain collaboration has been verified to have a positive impact on the performance but only a limited number of studies investigate it as a risk mitigation tool. The current study presents a guiding framework for identification, assessment, and migration of environment side risks for Malaysian manufacturing. A questionnaire has been developed and distributed by systemic probability sampling. Data have been collected from the Federation of Manufacturing Malaysia through an online survey. The data were purified from missing values and outliers and were analyzed through structural equational modeling through Smart PLS. A total of nine environment side risks were identified. In risk assessment, it has been found that an environment side risk has negative effects on supply chain performance. While these risks can be mitigated through supply chain collaboration, they cannot be mitigated completely. This study will help managers to understand how environment side risks are affecting enterprise performance and how they can avoid these risks. This study covers only environment side risks while future research can be on operational risks and various other approaches that can be proposed for mitigation.
\end{abstract}

Keywords-environment risks; supply chain; supply chain performance

\section{INTRODUCTION}

Any disruption, either natural or unnatural, has become the highest risk for business [1-3]. About $67 \%$ of managers agree that risk management is more important than before and $89 \%$ of companies accept that after financial crises their main concern is natural disasters [2]. In [1], it has been revealed that political uncertainties, natural disasters, and economic issues are among top risks. The last few decades the supply chain (SC) has gained notable attention due to globalization [4]. There are many examples that prove the value of SC risk management (SCRM), like a fire in New Mexico electronic chip manufacturing plant stopped the supplying to Ericsson and, as a result, the company bared a loss of $\$ 2.34$ billion [5]. Among the operation management fields, production inventory and SC management are considered the most studied research areas [6]. Malaysia has faced many SC issues that not only affect the enterprises, but also the overall economy, e.g. the 2008 airport closure in Thailand [1], maritime piracy in the Straits of Malacca [7], delays in physical distribution in electronic and electric industry [8], rapid technological changes [9], increased outsourcing, product variation and suppliers' defaults [10], oil prices, China economic slowdown and foreign capital outflow [11], natural hazards causing disasters like the loss of Malaysia Airlines 370, the devastation of Malaysia Airline over Ukraine, and floods [12] and the operation blocking by Greenpeace of the Malaysian palm oil company IOI, world's largest palm oil producer and trader, because of forest demolition and child labor [13]. From the SC viewpoint, these disruptions not only affect organizational performance but also disturb the other SC elements.

It can be concluded that natural disasters demand a comprehensive investigation of SC risks. Effective mitigation strategy can only be operationalized when risk is appropriately identified and assessed. Meanwhile, SC collaboration has been verified to have positive impact on performance, but only a 
limited number of studies investigate it as a risk mitigation tool. The current study proposes a guiding framework for identification, assessment, and mitigation of environment side risks for Malaysian manufacturing.

\section{LITERATURE REVIEW}

\section{A. Supply Chain Risk Management (SCRM)}

SCRM is vast in its objectives and has become more complex [14]. There is no clear definition of SCRM [15-17]. This study adopts the definition of SCRM as "the identification and management of risks for the supply chain, through a coordinated approach amongst supply chain members, to reduce supply chain vulnerability as a whole" [18] for several reasons. First, this definition covers all processes of SCRM, Second, this study aims to reduce vulnerability as a whole that means it focuses on the whole SC and all its members, not an organization only. Third, this definition proposed coordination among members as a mitigation strategy that is the current study's suggestion. Last, this definition conceptualizes the SC risks as does the current study.

\section{B. Risks Identification}

Effective risk management can only be made possible if risks are properly identified, whether it is dealing with quality or safety challenges, supply shortages, legal issues, security problems, regulatory and environmental compliance, natural disasters, or terrorism. Risk sources are "any variables which cannot be predicted with certainty and from which disruptions can emerge" [19]. Risk sources have become more essential as SC becomes more complex and modern. SCRM can be categorized according to its risk sources [20]. Authors in [9] revealed that the main function of SCRM is to identify the potential risk sources. Authors in [21] studied 90 articles on SC risk sources and concluded that $25 \%$ of articles used only supply side risks and very few applied disruption risks. This study follows the criteria of [22] and generates a pool of items, then by pretesting, pilot testing, and exploratory factor analysis purifies the items.

\section{Environment Side Risks}

Environment side risks have low probability but high consequences [23]. Natural disasters create hurdles in operations [24]. It has been mentioned above that nature can disrupt not only one enterprise but also the whole SC system. Fires in forests and peat have become a global threat. Smokes from these fires killed about 110000 humans in Southeast Asia and caused huge global warming through carbon emissions [25]. In some countries, regulations are a big hurdle in starting a business or operate it effectively. Administrative decisions sometimes can affect the performance badly [26] as do regulatory laws [27]. According to [28], any change in the political environment due to new laws or modifications in the old ones causes disruption in SC operations and may increase cost or even sometimes halt production. It has been proved that regulation disruptions reduce shareholder's wealth by $3.8 \%$ [28]. Environment side risks categories are political instability, macroeconomic uncertainties, social uncertainties, natural uncertainties like diseases or epidemics, natural disasters, and terror attacks [27].

\section{Assessment}

It has been proved that environment side risks affect performance [29-31]. Relevant studies have been done in other regions, but now there is severe need to apply SCRM in Malaysia. The importance of environment side risks can be realized from the example of the Malaysian palm oil company IOI incident mentioned above [13]. It has been found that environment side risks have variation in effects, some studies found significant effects while some did not. Based on the literature review the below hypothesis has been developed to assess the environment side risks:

$\mathrm{H}_{1}$ : Environment side risks have negative effects on supply chain performance for Malaysian manufacturing.

\section{E. Supply Chain Performance (SCP)}

Deciding for an appropriate combination of performance indicators for measuring SCP is always challenging [32]. Performance measures should have some characteristics like sustainability, relevance, effectiveness, coherence, efficiency, and robustness [33]. Risk sources in SC, and risk mitigation approaches have been adapted from different studies, in which multiple ways were used to measure performance. The current study adopts the indicators of performance measure from [34], which are product quality, order fill capacity, delivery dependability, delivery speed and customer satisfaction as mentioned in Table I. In [34], risk sources and collaboration that affect performance are discussed. The numerous problems of current performance measures and their solutions in detail are discussed. So, [34] is the closest, most updated and comprehensive relevant study, to the best of our knowledge, so that is why this study adopts indicators from there.

TABLE I. DESCRIPTIVE INFORMATION

\begin{tabular}{|c|c|c|}
\hline Business incorporation & No. of respondents & (\%) \\
\hline Private Limited & 219 & 64 \\
\hline Public Limited & 66 & 20 \\
\hline Partnership & 38 & 11 \\
\hline Sole Proprietorship & 19 & 1 \\
\hline Employee experience (years) & & \\
\hline $1-5$ & 161 & 48 \\
\hline $6-10$ & 90 & 26 \\
\hline $11-15$ & 56 & 16 \\
\hline $16-20$ & 24 & 1 \\
\hline 21 and more & 11 & 1 \\
\hline Departmental position & & \\
\hline Purchase & 34 & 11 \\
\hline Logistic/supply chain & 40 & 12 \\
\hline Production and operation & 64 & 19 \\
\hline Sales and distribution & 71 & 21 \\
\hline Finance/HR/IT & 70 & 21 \\
\hline General managers (Director, CEO etc.) & 58 & 14 \\
\hline
\end{tabular}

\section{F. Mitigation}

After a clear understanding of risk, the enterprise needs to take appropriate measures to mitigate it. SCRM practices cover a set of approaches and strategies that effectively and efficiently integrate stakeholders to improve SC and overall business performance [35]. There are numerous approaches to deal with risks, deciding which one to adopt depends upon the situation [36]. According to [37], global SC risk mitigation 
strategies are SC collaboration, excess of inventory and other sources, visibility system, redesign of network and product. Authors in [38] summarize SCRM approaches as take the risk (keep excess resources), share the risk (share it with partners), transfer the risk (agreements with suppliers to send all risk to them), reduce the risk (take measures to minimize the intensity of risks), eliminate the risk and monitor the risk (keep eyes on suppliers or any entity that can affect negatively). In [39], $6 \mathrm{SC}$ mitigation strategies are presented: postponement, speculation, hedging, control, security and avoidance. The rapid growth in global SC requires interconnectedness among members. As a result, a high level of interdependency and complexity were developed in the SC [4, 31, 40]. Empirical studies proved that $\mathrm{SC}$ collaboration increases performance $[41,42]$. Authors in [34] revealed that SC collaboration reduces risks. As an example the auto part supplier Takata Corp. is referred. In March 2006, one of its airbag production facilities was destroyed, but its customers did not face a disruption because Takata's competitors worked together in order to support its customers [43]. Consequently, there are many studies available on SC mitigation approaches. This study is limited to the collaboration with suppliers and customers. Currently, more organizations are depending on their fellows in a SC network, so the competition is not among organizations but among networks [7].

\section{G. Supply Chain Collaboration}

Authors in [44] reported that currently organizations firmly need to employ collaboration with external partners to meet global challenges. Authors in [45] describe the need for an explanation of the relationship among partners SC in SC collaboration. Authors in [21] state an example of how Japanese automobiles defeated U.S. industry. It is revealed that the only reason behind this success is the high dependability of external collaborative partners. According to a global survey, managers report that the most predominant and daunting risks to their supply chains are those controllable risks associated with the performance of their SC partners [46]. There is a strong bond between an organization's information and joint planning with their stakeholders and organizational performance in risk mitigation [47]. Collaboration with trading partners should be the main focus for better performance [48]. Collaboration has improved approximately $23.7 \%$ of enterprises' performance variability [49] and it explained 8.5\% of organizations' performance variability in Malaysia [50]. Conclusively, collaboration through information processing has become crucial in highly uncertain environments [51]. It has been revealed that $53 \%$ articles in SC consist of theoretical studies while the remaining are empirical or mixed. The majority of empirical studies consist of two major sectors: automobile and electronic. It can be concluded that there is a further need to elaborate on other sectors [52]. Based on the literature review the following hypothesis has been developed

$\mathrm{H}_{2}$ : SC collaboration positively moderates the relationship between environment side risks (ER) and SCP.

\section{H. Research Framework}

Figure 1 shows the proposed research framework based on the developed hypotheses. This framework consists of one independent variable (environment side risks) that has a negative effect on the dependent variable (SCP) and one moderator (SC collaboration). It has been proposed that $\mathrm{SC}$ collaboration positively moderates the negative relationship between ER and SCP for Malaysian manufacturing companies.

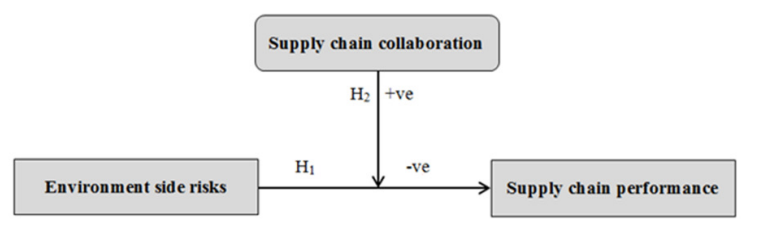

Fig. 1. Research framework

\section{RESEARCH METHODOLOGY}

This is an empirical investigation of the hypotheses. A questionnaire has been distributed by probabilistic systematic sampling to the registered manufacturing organizations in Federation of Manufacturing Malaysia-2017. The total number of listed manufacturing enterprises is 2250 and by applying Krejcie \& Morgan sampling technique the sample size should be 331 for 2400 population [53]. A questionnaire to 480 organizations was sent and after 2 reminders within one month, a total of 358 responses were received. The respondents were given 7 options (7-point Likert scale) from strongly disagree to strongly agree for each question. Meanwhile, SCC measurements have been adopted from [21] (Table III).

TABLE II. SCP MEASUREMENTS [21]

\begin{tabular}{|c|c|}
\hline Variable & Items \\
\hline \multirow{4}{*}{$\begin{array}{c}\text { Supply chain } \\
\text { performance }\end{array}$} & Quality (overall product or service quality) \\
\cline { 2 - 2 } & Customer satisfaction \\
\cline { 2 - 2 } & Order fill capacity (provision of desired quantities on a \\
& consistent basis) \\
\cline { 2 - 2 } & $\begin{array}{c}\text { Delivery speed (time between order and customer delivery) } \\
\text { Dependability (anticipated delivery dates and } \\
\text { quantities on a consistent basis) }\end{array}$ \\
\hline
\end{tabular}

\section{RESULTS AND DISCUSSION}

Data have been analyzed through SPSS. At first, special codes have been assigned to all items and data have been put in an SPSS file. The second step was a manual screening of data, responses with high mission values and the same responses were deleted. Furthermore, data have been cleaned from missing values and outliers. Then, descriptive analysis has been performed with two demographics: industry related and employee related. The validity and reliability of the questionnaire have been assessed and lastly, the structural model has been evaluated by multiple regressions.

\section{A. Descriptive Information}

The studied population consists of business incorporations belonging to FMM 2017 and its descriptive information are shown in Table I. Most of the respondents (64\%) are from private limited organizations. Most of the respondents have less than 5 years of experience. The highest numbers of respondents are from sales, distribution, finance, HR, IT, and production and operation. Although the lowest number is from purchase, still it is enough for representation. 


\section{B. Measurement Model}

Reliability and validity are crucial for the quality of any research [54]. This study calculated composite reliability, convergent validity, and discriminant validity to verify the measurement model. Smart PLS 3 has been used for reliability and validity. Figure 2 shows the PLS algorithm results for a direct relationship while Figure 3 illustrates the PLS bootstrapping for the direct model. Moderation hierarchy analysis has been applied to assess mitigation. Figure 4 explains the PLS algorithm for the moderation model and Figure 5 shows the PLS bootstrapping for the moderation model.

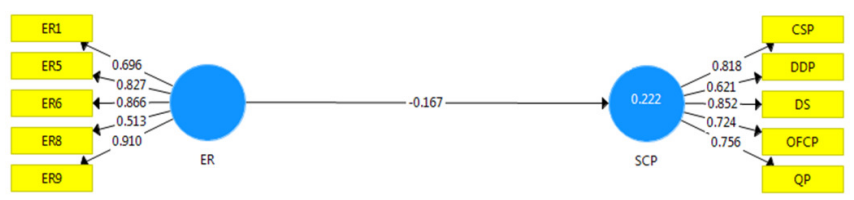

Fig. 2. PLS algorithm

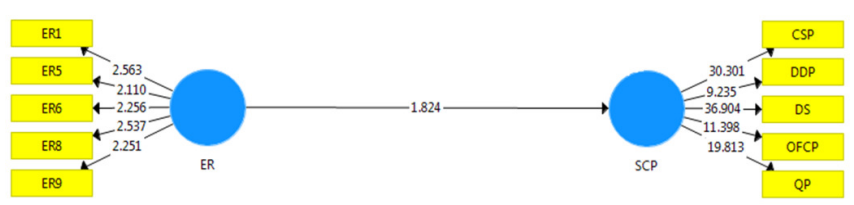

Fig. 3. PLS bootstrapping for the direct model

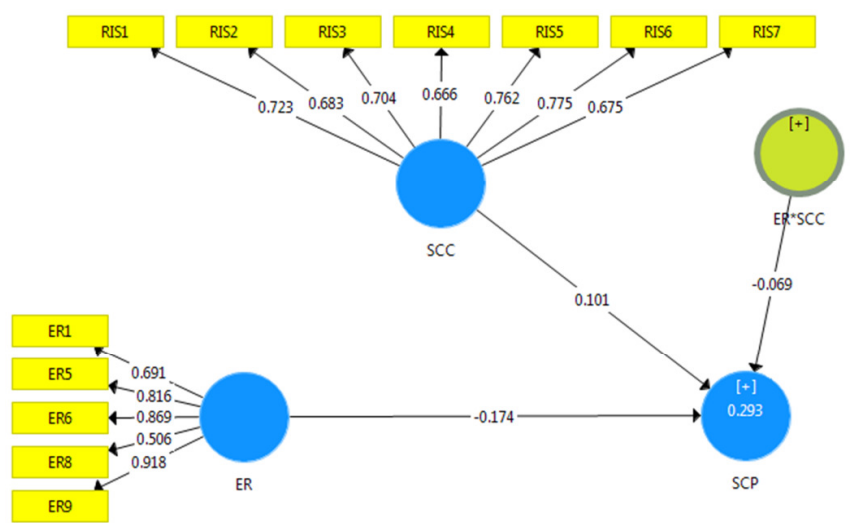

Fig. 4. PLS algorithm for the moderation model

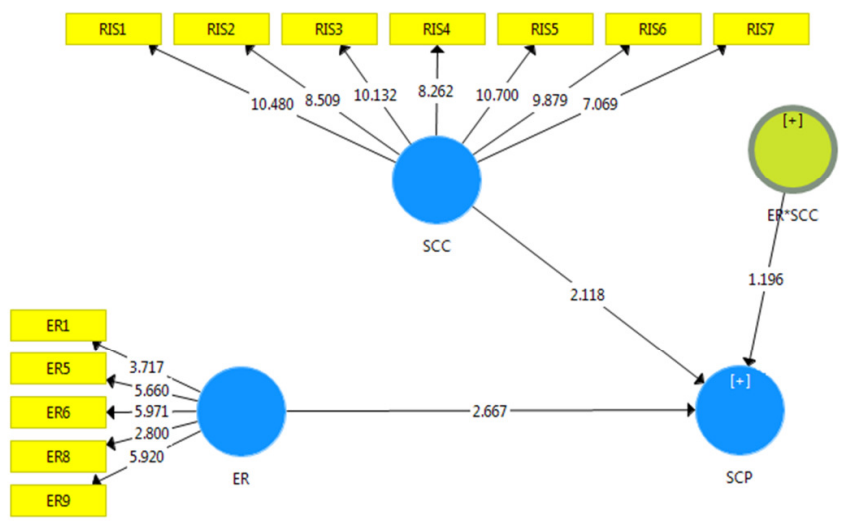

Fig. 5. PLS bootstrapping for the moderation model
The range of composite reliability is between 0 and 1 , the higher the values, the higher the reliability. Its threshold value is considered good at 0.70 . Composite reliability below 0.60 indicates a deficiency of internal consistency and above 0.90 is not required as it means that all the items are measuring the same phenomenon [55]. An AVE value of 0.50 or higher indicates that the construct explains more than half of the variance of its indicators. While an AVE of less than 0.50 indicates that more error remains in the items than the variance explained by the construct [55]. High factor loadings indicate convergence for a latent construct. Average of all factor loadings should be statistically significant, a good rule is that standardized loading estimations should be at least 0.5 or higher and 0.7 or higher is considered ideal [56]. Most of the researches prefer Fornell-Larcker criterion as a conservative approach [57]. It compares the square root of the AVE values with the latent variable correlations. Specifically, the square root of each construct's AVE should be greater than its highest correlation with any other construct.

TABLE III. FACTOR LOADING

\begin{tabular}{|c|c|c|}
\hline $\begin{array}{c}\text { Item } \\
\text { code }\end{array}$ & Items & $\begin{array}{c}\text { Factor } \\
\text { loading }\end{array}$ \\
\hline ER1 & $\begin{array}{c}\text { Policy uncertainty (changes in the political environment } \\
\text { due to the introduction of new laws) }\end{array}$ & 0.691 \\
\hline ER5 & Non-availability of skilled manpower & 0.827 \\
\hline ER6 & Natural disasters (e.g. earthquake, tsunami) & 0.866 \\
\hline ER8 & $\begin{array}{c}\text { Administrative barriers for the setup or operation of SCs } \\
\text { (e.g. authorizations) }\end{array}$ & 0.513 \\
\hline ER9 & Technological changes & 0.910 \\
\hline SCC 1 & $\begin{array}{c}\text { We and our key SC partners inform each other in advance } \\
\text { of changing needs }\end{array}$ & 0.723 \\
\hline SCC 2 & $\begin{array}{c}\text { We include our key SC partners in our planning and goal- } \\
\text { setting activities }\end{array}$ & 0.683 \\
\hline SCC 3 & $\begin{array}{c}\text { We and our key SC partners jointly work out solutions for } \\
\text { main changes }\end{array}$ & 0.704 \\
\hline SCC 4 & $\begin{array}{c}\text { We facilitate our key SC partners' ability to seek } \\
\text { technical, operational, and financial assistance from us }\end{array}$ & 0.666 \\
\hline SCC 5 & We allocate benefits fairly to our key SC partners & 0.762 \\
\hline SCC 6 & We are willing to make adjustments with our SC partners & 0.775 \\
\hline SCC 7 & We regularly solve problems jointly with our SC partners & 0.675 \\
\hline
\end{tabular}

TABLE IV. VALIDITY AND RELIABILITY

\begin{tabular}{|c|c|c|}
\hline Constructs & Environmental side risks & SC collaboration \\
\hline Number of items & 5 & 5 \\
\hline Cronbach's $\boldsymbol{\alpha}$ & 0.854 & 0.830 \\
\hline Composite reliability & 0.880 & 0.871 \\
\hline $\begin{array}{c}\text { Average variance } \\
\text { extracted }\end{array}$ & 0.602 & 0.577 \\
\hline
\end{tabular}

TABLE V. DISCRIMINANT VALIDITY

\begin{tabular}{|c|c|c|}
\hline & ER & SCP \\
\hline ER & 0.776 & \\
\hline SCP & 0.149 & 0.759 \\
\hline
\end{tabular}

\section{Structural Model}

This study applied Smart PLS to the examined coefficient of determination $\mathrm{R}^{2}$, standardized path (Beta coefficient) and $\mathrm{t}$ statistics. A standardized path value shows the strength of the relationship. If the value is negative this shows negative relationship between the variables and vice versa. Statistical 
level of t-value shows the significant level of a relationship. This study chose $10 \%$ level of significance as this is predictive study so chances of error are high. $\mathrm{R}^{2}$ examines the effect of the independent variables on the dependent variables. Meanwhile, both independent and moderator variables are continuous so interaction terms were calculated from standardized values to avoid collinearity problem. The aim of this study is to evaluate the effects of ER on SCP. This effect is calculated by the coefficient of determination $R^{2} \cdot R^{2}$ is a measure of the proportion of an endogenous construct's variance that is explained by its predictor constructs. Figure 2 applies PLS and it was found that $\mathrm{R}^{2}=0.22$. It means all ER caused a decrease in performance by -0.167 or $-16.7 \%$. The low value of $\mathrm{R}^{2}$ is not surprising as it is consistent with previous studies. It is known that SCP is dependent on numerous factors besides SC risks [27, 28]. In Figure 3 the value of t-statistic is 1.824 which is greater than 1.645 . It means ER has a significant negative relationship on performance. Thus $\mathrm{H}_{1}$ is accepted. There is a need to know that either SCC has the significant positive effect of SCC or not before analyzing SCC as a moderator. Figure 4 shows that the value of $\mathrm{R}^{2}$ is 0.293 which means that all variables contribute $29.3 \%$. Previous with one independent variable the value of $\mathrm{R}^{2}$ was $22 \%$. Thus, there is decrease that means SCC has effect on SCP. Furthermore, in Figure 5 the t-value is 1.196 that is less than $1.645 \mathrm{So}_{2}$ is rejected. It can be concluded that ER has a negative and significant effect of SCP while SCC is positively moderating the relationship but this relationship is not significant.

\section{DISCUSSION}

The current study proposed that environment side risks negatively affect SCP for Malaysian manufacturing and this hypothesis is accepted. These findings are in line with the findings in [58-60]. However, according to authors in [22] environment side risks rank last when compared to others, but this study is limited to Indian heavy industry only, and it includes limited risk factors under environment side risks. This study anticipated that SC collaboration moderates the relationship between environment side risks and SCP. Figure 4 shows that path coefficient for environment side risks is 0.069 while it can be found in Figure 5 that the t-value is 1.196 , whereas path coefficient for a direct relationship between environment side risks and SCP in Model 1 is -0.167 . This means that $\mathrm{SC}$ collaboration reduces the negativity between the $\mathrm{SC}$ risk sources and SCP. These findings are in line with the findings in $[61,62]$. Meanwhile, some other studies argue that collaboration/integration mitigate the environment side risks [63-66]. On the other hand, authors in [67] empirically verified that higher environmental uncertainties reduce the resource sharing among organizations, but, in that study, resource sharing meant sharing information and assets for the humanitarian organization in Southeast Asia. It is explained that only humanitarian organizations do not need coordination because they work in extreme levels of uncertainty anyway (disasters, donors' generosity, beneficiaries' demand etc.), so it is very difficult for them to supply and coordinate effectively. Furthermore, regional infrastructure in numerous disaster areas may not be available, and the extent of post-disaster infrastructure disruption may not be predictable.

\section{CONCLUSION}

It can be concluded that Malaysian manufacturing is risky in terms of environment side risks. This study identified 9 types of risks and after systemic process 5 types were found dangerous. Rapid technological changes are the highest effecting risk and natural disasters are a highly affecting risk. The availability of skilled and technical workers is also affecting performance. Administration barriers and policy uncertainty are key reasons for performance decline. There are various approaches for dealing with these risks but collaboration among partners is considered the best approach. Although SCC will not mitigate the effect significantly, it will reduce the uncertain situation and will help the enterprise to deal with a halt. Managers must understand that Malaysian manufacturing is in a dangerous situation and learn how to deal with this danger. Future research can explore operational risks and various other mitigation strategies or approaches.

\section{REFERENCES}

[1] K. Kungwalsong, Managing Disruption Risks in Global Supply Chains, PhD Thesis, The Pennsylvania State University, 2013

[2] Harvard Business Review, "Risk Management in a Time of Global Uncertainty", available at: https://hbr.org/2012/03/risk-management-ina-time-of-g.html, 2011

[3] World Economic Forum, Global Risks 2010: A Global Risk Network Report, World Economic Forum, 2010

[4] M. Kamalahmadi, M. M. Parast, "A review of the literature on the principles of enterprise and supply chain resilience: Major findings and directions for future research", International Journal of Production Economics, Vol. 171, No. 1, pp. 116-133, 2016

[5] B. Yang, Y. Yang, "Postponement in supply chain risk management: a complexity perspective", International Journal of Production Economics, Vol. 48, No. 7, pp. 1901-1912, 2010

[6] S. K. Paul, R. Sarker, D. Essam, "Managing risk and disruption in production-inventory and supply chain systems: A review", Journal of Industrial and Management Optimization, Vol. 12, No. 3, pp. 10091029,2016

[7] G. Singh, N. A. Wahid, "Supply Chain Risk Management: A Review", International Journal of Supply Chain Management, Vol. 3, No. 3, pp. 59-67, 2014

[8] A. A. M. Hassan, A. Zaharudin, A. M. Yunus, "Delays in physical distribution: a case study of sony supply chain solutions Malaysia", in: The Proceedings of The 4th International Seminar on Entrepreneurship and Business (ISEB 2015), Faculty of Entrepreneurship and Business,UMK, pp. 658-674, 2015

[9] S. Yaakub, H. K. Mustafa, "Supply Chain Risk Management for the SME's", Academic Journal of Interdisciplinary Studies, Vol. 4, No. 1, pp. $151-158,2015$

[10] N. Hudin, A. B. A. Hamid, "Supply Chain Risk Management in Automotive Small and Medium Enterprises in Malaysia”, Applied Mechanics and Materials, Vol. 773-774, pp. 799-803, 2015

[11] B. S. Saleem, "Malaysia's Economic Challenges?: Implications of Ringgit's Fall. A Report", RSIS Commentary, No. 177, 2015

[12] Aon Risk Solutions, Global Risk Management Survey, AON, 2015

[13] Maritime Executive, "Greenpeace blocks Malaysian palm oil company IOI at Rotterdam Port", available at: https://maritimeexecutive.com/article/greenpeace-block-palm-oil-delivery-at-rotterdamport?mod=djemlogistics, 2016

[14] R. C. Basole, M. A. Bellamy, H. Park, J. Putrevu, "Computational Analysis and Visualization of Global Supply Network Risks", IEEE Transactions on Industrial Informatics, Vol. 12, No. 3, pp. 1206-1213, 2016

[15] M. S. Shahbaz, R. Z. R. M. Rasi, M. F. Bin Ahmad, and F. Rehman, "What is supply chain risk management? A review", Journal of 
Computational and Theoretical Nanoscience., Vol. 23, No. 9, pp. 92339238, 2017

[16] M. S. Sodhi, B. G. Son, C. S. Tang, "Researchers' Perspectives on Supply Chain Risk Management", Production and Operations Management, Vol. 21, No. 1, pp. 1-13, 2012

[17] O. Tang, S. N. Musa, "Identifying risk issues and research advancements in supply chain risk management", International Journal of Production Economics, Vol. 133, No. 1, pp. 25-34, 2011

[18] U. Juttner, H. Peck, M. Christopher, "Supply chain risk management: outlining an agenda for future research", International Journal of Logistics, Vol. 6, No. 4, pp. 197-210, 2003

[19] U. Juttner, "Supply chain risk management: Understanding the business requirements from a practitioner perspective", International Journal of Logistics Management, Vol. 16, No. 1, pp. 120-141, 2005

[20] A. Lockamy III, K. McCormack, "Analysing risks in supply networks to facilitate outsourcing decisions", International Journal of Production Economics, Vol. 48, No. 2, pp. 593-611, 2010

[21] J. Chen, The Role of Supply Chain Collaboration in Supply Chain Risk Mitigation, PhD Thesis, Monash University, 2012

[22] M. Punniyamoorthy, N. Thamaraiselvan, L. Manikandan, "Assessment of supply chain risk: scale development and validation", Benchmarking: an International Journal, Vol. 20, No. 1, pp. 79-105, 2013

[23] A. M. Knemeyer, W. Zinn, C. Eroglu, "Proactive planning for catastrophic events in supply chains", Journal of Operations Management, Vol. 27, No. 2, pp. 141-153, 2009

[24] R. Tummala, T. Schoenherr, "Assessing and managing risks using the Supply Chain Risk Management Process (SCRMP)", Supply Chain Management: an International Journal, Vol. 16, No. 6, pp. 474-483, 2011

[25] Greenpeace Southeast Asia, "Stop the haze", available at: http://www.greenpeace.org/seasia/stop-the-haze,

[26] K. B. Hendricks, V. R. Singhal, "The effect of supply chain glitches on shareholder wealth", Journal of Operations Management, Vol. 21, No. 5, pp. 501-522, 2003

[27] S. M. Wagner, C. Bode, "An Empirical Examination of Supply Chain Performance Along Several Dimensions of Risk", Journal of Business Logistics, Vol. 29, No. 1, pp. 307-325, 2008

[28] G. A. Zsidisin, B. N. Petkova, L. Dam, "Examining the influence of supply chain glitches on shareholder wealth: does the reason matter?", International Journal of Production Research, Vol. 54, No. 1, pp. 69-82, 2015

[29] M. S. Shahbaz, R. Z. R. M. Rasi, M. F. Bin Ahmad, S. Sohu, "The impact of supply chain collaboration on operational performance: Empirical evidence from manufacturing of Malaysia", International Journal of Advanced and Applied Sciences, Vol. 5, No. 8, pp. 64-71, 2018.

[30] M. Christopher, B. Gaudenzi, "Managing risks in sustainable supply chains", Sinergie Italian Journal of Management, Vol. 33, No. 96, pp. $57-73,2015$

[31] M. Christopher, C. Mena, O. Khan, O. Yurt, "Approaches to managing global sourcing risk", Supply Chain Management: an International Journal, Vol. 16, No. 2, pp. 67-81, 2011

[32] N. Anand, N. Grover, "Measuring retail supply chain performance: Theoretical model using key performance indicators (KPIs)", Benchmarking: an International Journal, Vol. 22, No. 1, pp. 135-166, 2015

[33] M. S. Shahbaz, R. Z. R. M. Rasi, M. H. Zulfakar, M. F. Bin Ahmad, Z. Abbas, M. F. Mubarak, “A Novel Metric of Measuring Performance for Supply Chain Risk Management: Drawbacks and Qualities of Good Performance", Journal of Fundamental and Applied Sciences, Vol. 10, No. 3S, pp. 967-988, 2018

[34] J. Chen, A. S. Sohal, D. I. Prajogo, "Supply chain operational risk mitigation: A collaborative approach", International Journal of Production Economics, Vol. 51, No. 7, pp. 2186-2199, 2013

[35] I. Sukati, A. B. Hamid, R. Baharun, R. M. Yusoff, "The Study of Supply Chain Management Strategy and Practices on Supply Chain
Performance", Procedia - Social and Behavioral Sciences, Vol. 40, pp. 225-233, 2012

[36] Alhosani, S. M. Zabri, “A uniform supply chain management framework for oil and gas sector: A preliminary review", International Journal of Advanced and Applied Sciences, Vol. 5, No. 2, pp. 19-24, 2018

[37] R. B. Handfield, K. McCormack, Supply Chain Risk Management Minimizing Disruptions in Global Sourcing, New York and London: Auerbach Publications Taylor \& Francis Group, 2008

[38] A. R. Ravindran, D. P. Warsing, Supply Chain Engineering: Models and Applications, CRC Press Taylor \& Francis Group, 2013

[39] I. Manuj, J. T. Mentzer, "Global supply chain risk management strategies", International Journal of Physical Distribution \& Logistics Management, Vol. 38, No. 3, pp. 192-223, 2008

[40] E. Fradinata, S. Suthummanon, and W. Suntiamorntut, "Reducing the bullwhip effect from signal demand of hybrid artificial neural network models of supply chain in Indonesia", International Journal of Advanced and Applied Sciences, Vol. 4, No. 10, pp. 64-75, 2017

[41] T. Ng, M. Ghobakhloo, "What derives lean manufacturing effectiveness : An interpretive structural model", International Journal of Advanced and Applied Sciences, Vol. 4, No. 8, pp. 104-111, 2017

[42] U. S. Resilience Project, Dow Chemical: Strategies for Supply Chain Security and Sustainability, 2011

[43] S. M. Wagner, C. Bode, "An empirical investigation into supply chain vulnerability", Journal of Purchasing and Supply Management, Vol. 12, No. 6, pp. 301-312, 2006

[44] K. Kauppi, A. Longoni, F. Caniato, M. Kuula, "Managing country disruption risks and improving operational performance: risk management along integrated supply chains", International Journal of Production Economics, Vol. 182, pp. 484-495, 2016

[45] M. S. Shahbaz, R. Z. R. M. Rasi, M. H. Zulfakar, M. F. Bin Ahmad, M. M. Asad, "Theoretical Framework Development for Supply Chain Risk Management for Malaysian Manufacturing", International Journal of Supply Chain Management, Vol. 7, No. 6, pp. 325-338, 2018

[46] B. M. Byrne, Structural Equation Modeling with AMOS:Basic Concepts, Applications, and Programming, Psychology Press, 2010

[47] D. E. Cantor, J. Blackhurst, M. Y. Pan, M. Crum, "Examining the role of stakeholder pressure and knowledge management on supply chain risk and demand responsiveness", International Journal of Logistics Management, Vol. 25, No. 1, pp. 202-223, 2014

[48] A. Bin Daud, "A Study on Lean Supply Chain Implementation in Malaysia's Electrical and Electronics Industry, Unpublished MSc Thesis, USM, Malaysia, 2010

[49] B. B. Flynn, B. Huo, X. Zhao, "The impact of supply chain integration on performance: A contingency and configuration approach", Journal of Operations Management, Vol. 28, No. 1, pp. 58-71, 2010

[50] F. S. R. Effendi, "The Determinants of Logistics Efficiency in Malaysia", available at https://papers.ssrn.com/sol3/papers.cfm? abstract_id=2702315, 2015

[51] C. Ataseven, A. Nair, "Assessment of Supply Chain Integration and Performance Relationships: A Meta-Analytic Investigation of the Literature", International Journal of Production Economics, Vol. 185, pp. 252-265, 2017

[52] M. S. Shahbaz, A. F. Chandio, M. Oad, A. Ahmed, R. Ullah, "Stakeholders' Management Approaches in Construction Supply Chain : a New Perspective of Stakeholder's Theory", International Journal of Sustainable Construnction Engineering \& Technology, Vol. 9, No. 2, pp. 16-26, 2018

[53] R. V. Krejcie, D. W. Morgan, "Determining Sample Size for Research Activities", Educational \& Psychological Measurement, Vol. 30, pp. 607-610, 1970

[54] M. Saunders, P. Lewis, A. Thornhill, Research Methods For Business Students, Pearson Education Ltd, 2007

[55] J. F. J. Hair, G. T. M. Hult, C. M. Ringle, M. Sarstedt, A Primer on Partial Least Squares Structural Equation Modeling (PLS-SEM), SAGE Publications, 2014

[56] J. F. Hair, W. C. Black, B. J. Babin, R. E. Anderson, Multivariate Data Analysis, Pearson Education Ltd, 2014 
[57] J. Henseler, C. M. Ringle, M. Sarstedt, "A new criterion for assessing discriminant validity in variance-based structural equation modeling", Journal of the Academy of Marketing Science, Vol. 43, No. 1, pp. 115135,2014

[58] N. Karia, M. Soliman, "Factors affecting enterprise resource planning (ERP) systems adoption among higher education institutions in Egypt", International Journal of Advanced and Applied Sciences, Vol. 4, No. 5 , pp. 144-151, 2017

[59] S. S. K. Sharma, A. Bhat, "Identification and assessment of supply chain risk: development of AHP model for supply chain risk prioritisation", International Journal of Agile Systems and Management, Vol. 5, No. 4, pp. 350-369, 2012

[60] V. Sanchez-Rodrigues, A. Potter, M. N. Naim, "The impact of logistics uncertainty on sustainable transport operations", International Journal of Physical Distribution \& Logistics Management, Vol. 40, No. 1/2, pp. 6183,2010

[61] C. Y. Wong, S. Boon-Itt, C. W. Y. Wong, "The contingency effects of environmental uncertainty on the relationship between supply chain integration and operational performance", Journal of Operations Management, Vol. 29, No. 6, pp. 604-615, 2011

[62] M. Kim, S. Chai, "Assessing the impact of business uncertainty on supply chain integration", International Journal of Logistics Management, Vol. 27, No. 2, pp. 463-485, 2016

[63] D. W. Kwak, Risk Management in International Container Logistics Operations: Risk Analysis and Mitigating Strategies, PhD Thesis, Cardiff University, 2014

[64] P. Hoffmann, H. Schiele, K. Krabbendam, "Uncertainty, supply risk management and their impact on performance", Journal of Purchasing and Supply Management, Vol. 19, No. 3, pp. 199-211, 2013

[65] Q. Zhu, H. Krikke, M. C. J. Caniels, Y. Wang, "Twin-objective supply chain collaboration to cope with rare but high impact disruptions whilst improving performance", International Journal of Logistics Management, Vol. 28, No. 2, pp. 488-507, 2017

[66] X. Brusset, C. Teller, "Supply chain capabilities, risks, and resilience", International Journal of Production Economics, Vol. 184, pp. 59-68, 2017

[67] A. Maghsoudi, A. Pazirandeh, "Visibility, resource sharing and performance in supply chain relationships: insights from humanitarian practitioners", Supply Chain Management: an International Journal, Vol. 21, No. 1, pp. 125-139, 2016 